\title{
Adrenergic Mechanisms in the Hyperglycaemia and Hyperinsulinaemia of Diabetic KK Mice
}

\author{
K. Fujimoto ${ }^{1}$, T. Sakaguchi ${ }^{1}$, and M. $\mathrm{Ui}^{2}$ \\ ${ }^{1}$ Research and Development Laboratories, Hoechst Japan Limited, Saitama, and ${ }^{2}$ Department of Physiological Chemistry, \\ Faculty of Pharmaceutical Sciences, Hokkaido University, Sapporo, Japan
}

\begin{abstract}
Summary. Simultaneous occurrence of hyperglycaemia (up to $300 \mathrm{mg} / 100 \mathrm{ml}$ ) and hyperinsulinaemia (up to $1200 \mu \mathrm{U} / \mathrm{ml}$ ) was evident in the fed state in genetically diabetic KK mice, indicating insulin resistance. The hyperinsulinaemia was enhanced by $\alpha$-adrenergic blockade and alleviated by B-blockade. Epinephrine-induced hyperglycaemia and isoproterenol-induced hyperinsulinaemia, both of which could be blocked by $\beta$-adrenergic antagonists, were more marked in KK mice than in ICR mice. A possible significance of adrenergic mechanisms is discussed with respect to the aetiology of the metabolic disturbances characteristic of KK mice.
\end{abstract}

Key words: Hyperglycaemia, hyperinsulinaemia, genetically diabetic KK mice, epinephrine, isoproterenol, $\alpha$-adrenergic antagonist, $\beta$-adrenergic antagonist.

Diabetic syndromes characteristic of the KK mouse [1] have been described by several investigators $[2,3$, 4]. Dulin and Wyse [4] have reported the simultaneous occurrence of hyperglycaemia and hyperinsulinaemia, indicating that they are insulin resistant under these conditions. The purpose of the present study was to investigate the possible involvement of adrenergic mechanisms in the hyperglycaemia and hyperinsulinaemia characteristic of this diabetic strain of mice.

\section{Materials and Methods}

\section{Animals}

KK mice used were males from 4 to 30 weeks old from the colony in the Research and Development Laboratories, Hoechst, Japan, derived from the breeding stock obtained from Central Institute for Experimental Animals (Kawasaki, Japan). ICR mice purchas- ed from CLEA Japan, (Tokyo, Japan) were used as nondiabetic controls. Animals were housed in groups of three per plastic cage with cedar shavings on the floor. They had free access to water, and were either fed a pelleted diet (CLEA Stock Diet CA-2, CLEA Japan,) ad libitum or fasted for $16 \mathrm{~h}$ from $1700 \mathrm{~h}$ to $0900 \mathrm{~h}$ before use. They were maintained at a temperature of $23 \pm 1{ }^{\circ} \mathrm{C}$ and a relative humidity of $55 \pm 5 \%$.

In experiments in which the effects of adrenergic agonists and/ or antagonists were studied, the fasted or fed animals were first injected IP with $200 \mu \mathrm{g} / 10 \mathrm{~g}$ body wt of phentolamine (an $\alpha$ adrenergic antagonist) or propranolol (a $\beta$-adrenergic antagonist). Where indicated, epinephrine or isoproterenol was injected SC $30 \mathrm{~min}$ later at a dose of $5 \mu \mathrm{g} / 10 \mathrm{~g}$ body wt. Blood was collected $60 \mathrm{~min}$ after the injection of the antagonist for determination of blood glucose and plasma insulin.

\section{Blood Samples}

Blood $(20-100 \mu \mathrm{l})$ was usually obtained from unanaesthetised mice via the tail vein using a heparinised micropipette, and either haemolysed in a 100 -fold volume of distilled water or diluted with an equal volume of $0.154 \mathrm{~mol} / \mathrm{I}$ saline. The latter was centrifuged at $600 \mathrm{xg}$ for $5 \mathrm{~min}$ at $4^{\circ} \mathrm{C}$ to separate the diluted plasma. For determination of plasma insulin in the fasted state, a larger volume $(1 \mathrm{ml})$ of whole blood was withdrawn by cardiac puncture through a heparinised syringe under anaesthesia (sodium pentobarbitone $0.75 \mathrm{mg} / 10 \mathrm{~g}$ body wt, IP). The heparinised blood was centrifuged immediately at $600 \mathrm{xg}$ for $10 \mathrm{~min}$ at $4^{\circ} \mathrm{C}$ and the plasma stored at $-20^{\circ} \mathrm{C}$ until use.

\section{Analytical Procedures}

For measurement of blood glucose, the haemolysed blood $(0.02 \mathrm{ml})$ was added to $0.5 \mathrm{ml}$ each of $0.3 \mathrm{~mol} / 1 \mathrm{Ba}(\mathrm{OH})_{2}$ and $\mathrm{ZnSO}_{4}$. Glucose was analysed in the supernatant by a glucose oxidase method [5]. The diluted or undiluted plasma $(100 \mu 1)$ was assayed for immunoreactive insulin by double antibody radioimmunoassay [6] with mouse insulin as standard. The smallest amount of insulin assayable by this method was $0.5 \mu \mathrm{U}$, and interassay coefficient of variation was $4.2 \%$.

\section{Reagents}

The sources of the reagents used were: epinephrine (epinephrine bitartrate), Sigma Chemical (St. Louis, Mo.); phentolamine (Regitine), Ciba-Geigy (Tokyo); isoproterenol and sodium pentobarbitone Tokyo Chemical Industry Co. (Tokyo); propranolol, a gift from Hoechst (Frankfurt, West Germany); mouse insulin used 
Table 1. Development of hyperglycaemia and hyperinsulinaemia in fasted and fed KK mice with age

\begin{tabular}{lcccc}
\hline Mice & $\begin{array}{l}\text { Age } \\
\text { (week) }\end{array}$ & $\begin{array}{l}\text { Number of } \\
\text { animals }\end{array}$ & $\begin{array}{l}\text { Blood } \\
\text { glucose } \\
(\mathrm{mg} / 100 \mathrm{ml})\end{array}$ & $\begin{array}{l}\text { Plasma } \\
\text { insulin } \\
(\mu \mathrm{U} / \mathrm{ml})\end{array}$ \\
\hline Fasted & & & & \\
ICR & $5-12$ & 56 & $99 \pm 3$ & $16 \pm 1$ \\
KK & $7-8$ & 46 & $138 \pm 4^{\mathrm{a}}$ & $32 \pm 3^{\mathrm{a}}$ \\
& $12-13$ & 10 & $148 \pm 8^{\mathrm{a}}$ & $47 \pm 5^{\mathrm{a}}$ \\
& $15-16$ & 52 & $131 \pm 5^{\mathrm{a}}$ & $91 \pm 6^{\mathrm{a}}$ \\
& $25-30$ & 8 & $109 \pm 7$ & $70 \pm 11^{\mathrm{a}}$ \\
Fed & & & & \\
ICR & $8-22$ & 32 & $147 \pm 3$ & $35 \pm 3$ \\
KK & $4-5$ & 25 & $230 \pm 5^{\mathrm{a}}$ & $195 \pm 24^{\mathrm{a}}$ \\
& $8-9$ & 17 & $184 \pm 4^{\mathrm{a}}$ & $292 \pm 33^{\mathrm{a}}$ \\
& $10-12$ & 104 & $178 \pm 4^{\mathrm{a}}$ & $335 \pm 21^{\mathrm{a}}$ \\
& $15-16$ & 10 & $200 \pm 10^{\mathrm{a}}$ & $549 \pm 110^{\mathrm{a}}$ \\
& $20-24$ & 7 & $310 \pm 38^{\mathrm{a}}$ & $1089 \pm 257^{\mathrm{a}}$ \\
& $25-29$ & 5 & $312 \pm 33^{\mathrm{a}}$ & $1232 \pm 79^{\mathrm{a}}$ \\
\hline
\end{tabular}

Values show the mean \pm SEM. a Significantly different from ICR mice $(p<0.01)$

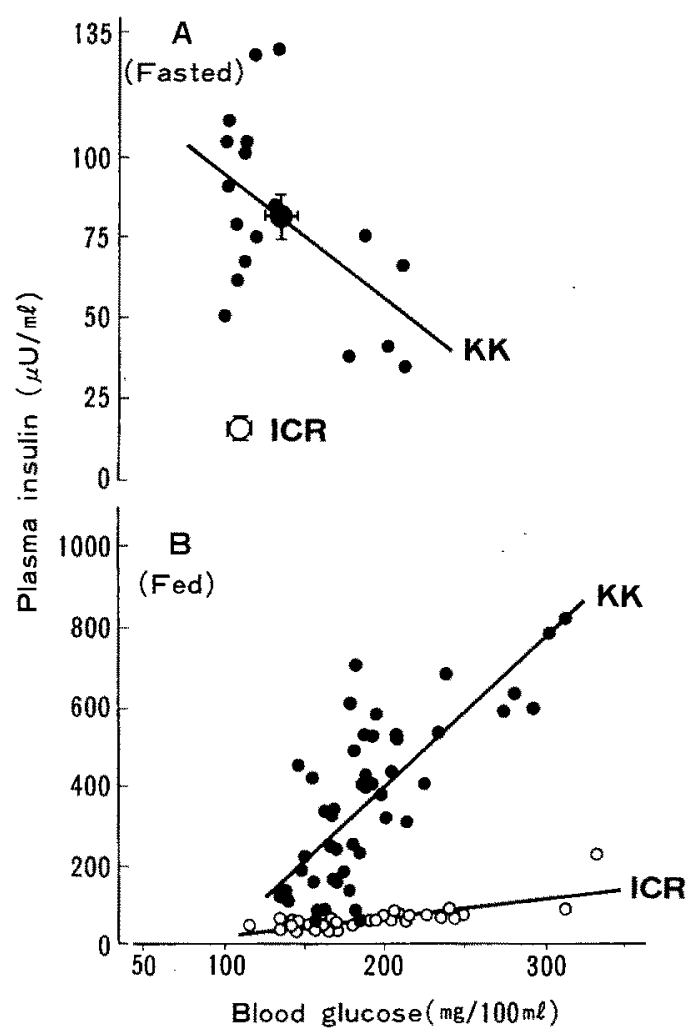

Fig. 1. Correlation between blood glucose and plasma insulin in fasted (panel A) and fed (panel B) KK (O) and ICR (O) mice. Animals of age between 10 and 15 weeks were used. In panel B, some of ICR mice were fed with $30 \%$ glucose solution $(0.1 \mathrm{ml} /$ $10 \mathrm{~g}$ body wt), and blood was collected one hour later. Regression lines are fitted by the method of the least-squares. In panel A, the mean \pm SEM is shown for ICR mice (a large open circle) and for KK mice (a large solid circle) as the standard of radioimmunoassay was a gift from Kodama Co., (Tokyo). Other reagents were of analytical grade from commercial sources.

\section{Statistical Methods}

Results are expressed as mean \pm SEM. The Student's unpaired ttest was used to assess the significance of difference unless otherwise indicated.

\section{Results}

Relation of Hyperinsulinaemia with Hyperglycaemia in KK Mice

KK mice of all ages showed hyperglycaemia in both the fed and fasted states compared with ICR mice (Table 1). Marked hyperinsulinaemia was also found in the KK mice in both the fasted and fed states. In contrast with the glucose findings plasma insulin values increased markedly with age reaching level of 5 times normal in the older KK mice in the fasted state and more than 30 times normal in the fed state.

There was an inverse correlation between the plasma insulin and blood glucose concentrations in fasted KK mice (Fig. 1A; $\mathrm{r}=-0.542, \mathrm{p}<0.05$ ). The regression line was well above the results for ICR mice suggesting insulin resistance of the KK mice. In contrast, in the fed KK mice there was a positive correlation between the concentrations of plasma insulin and blood glucose (Fig. 1B, $\mathrm{r}=$ $0.750, \mathrm{p}<0.01$ ). In the fed ICR mice there was also a positive correlation between these two parameters, though the slope $(50 \pm 17 \mu \mathrm{U} / \mathrm{mg})$ of the regression line was much flatter than the slope $(371 \pm 48 \mu \mathrm{U} /$ $\mathrm{mg}$ ) of the line for the fed $\mathrm{KK}$ mice. The difference in slope was highly significant $(\mathrm{p}<0.01)$.

\section{Effect of Adrenergic Antagonists on the Blood Glucose and Plasma Insulin Concentrations in KK Mice}

$\beta$-Adrenergic blockade in fasted KK mice by the injection of propranolol caused a significant decrease in plasma insulin (Table 2); the inverse correlation between blood glucose and plasma insulin concentration $(\mathrm{r}=-0.566, \mathrm{p}<0.05)$ as observed in fasted KK mice (Fig. 1 A) was observed even after propranolol. $\alpha$-Adrenergic blockade in fasted KK mice by phentolamine lowered the blood glucose and raised the plasma insulin concentrations (Table 2). There was a positive correlation between blood glucose and plasma insulin concentrations $(\mathrm{r}=0.706, \mathrm{p}<0.05)$ under these conditions. This exhibited a sharp contrast to the negative correlation similarly observed before phentolamine in the KK mice (Fig. 1 A) and 
Table 2. Effect of $\alpha$ - and $\beta$-adrenergic antagonists on blood glucose and plasma insulin concentrations in fasted KK and ICR mice

\begin{tabular}{lrc}
\hline Treatment & KK & ICR \\
\hline Blood glucose $(m g / 100 \mathrm{ml})$ & & \\
$\quad$ None & $141 \pm 11(18)$ & $96 \pm 6(20)$ \\
Phentolamine & $78 \pm 6(8)^{\mathrm{b}}$ & $66 \pm 5(7)^{\mathrm{b}}$ \\
$\quad$ Propranolol & $136 \pm 5(15)$ & $101 \pm 8(8)$ \\
Plasma insulin $(\mu \mathrm{U} / \mathrm{ml})$ & & \\
$\quad$ None & $81 \pm 7(18)$ & $16 \pm 2(20)$ \\
Phentolamine & $138 \pm 24(8)^{\mathrm{a}}$ & $37 \pm 5(7)^{\mathrm{a}}$ \\
Propranolol & $55 \pm 7(15)^{\mathrm{a}}$ & $19 \pm 3(8)$ \\
\hline
\end{tabular}

Values show the mean \pm SEM with number of animals in parentheses. ${ }^{a}(p<0.05)$ and ${ }^{b}(p<0.01)$ show significance levels for effect of the antagonist

after various doses of phentolamine $(10,50$ and $200 \mu \mathrm{g} / 10 \mathrm{~g}$ body wt) in fasted ICR mice ( $\mathrm{r}=$ $-0.612, \mathrm{p}<0.05, \mathrm{n}=13$, data not shown).

In the fed $\mathrm{KK}$ mice, the regression line reflecting the relation of plasma insulin to blood glucose concentrations was shifted far upwards by phentolamine and downwards by propranolol (Fig. 2). The slope of the regression line was also increased significantly by phentolamine ( $371 \pm 48$ to $1460 \pm 234 \mu \mathrm{U} / \mathrm{mg}$ ), suggesting that insulin secretion in response to hyperglycaemia was enhanced by $\alpha$-adrenergic blockade.

\section{Effect of Catecholamine Injection on the}

Concentration of Blood Glucose and Plasma Insulin in KK and ICR Mice

Epinephrine, at doses of 2 and $5 \mu \mathrm{g} / 10 \mathrm{~g}$ body wt, was injected SC into fasted KK and ICR mice. Changes in the blood glucose concentration are shown in Figure 3 as percent preinjection values. There was marked hyperglycaemia after epinephrine in both strains of mice. Hyperglycaemia was of longer duration in KK mice than in ICR mice.

The concentrations of blood glucose and plasma insulin at $30 \mathrm{~min}$ after injection of epinephrine or isoproterenol $(5 \mu \mathrm{g} / 10 \mathrm{~g})$ into $\mathrm{KK}$ and ICR mice are shown in Table 3 . Isoproterenol-induced hyperinsulinaemia attained its peak value around $30 \mathrm{~min}$ after injection. In some mice, phentolamine or propranolol was injected $30 \mathrm{~min}$ prior to the catecholamine. Epinephrine-induced hyperglycaemia was associated with the markedly lowered level of plasma insulin in KK mice but was not in ICR mice. This hypoinsulinaemic action of epinephrine was abolished by phentolamine although hyperglycaemia persisted. After $\beta$-adrenergic blockade, the plasma concentration of insulin was lowered by epinephrine in ICR mice as well.

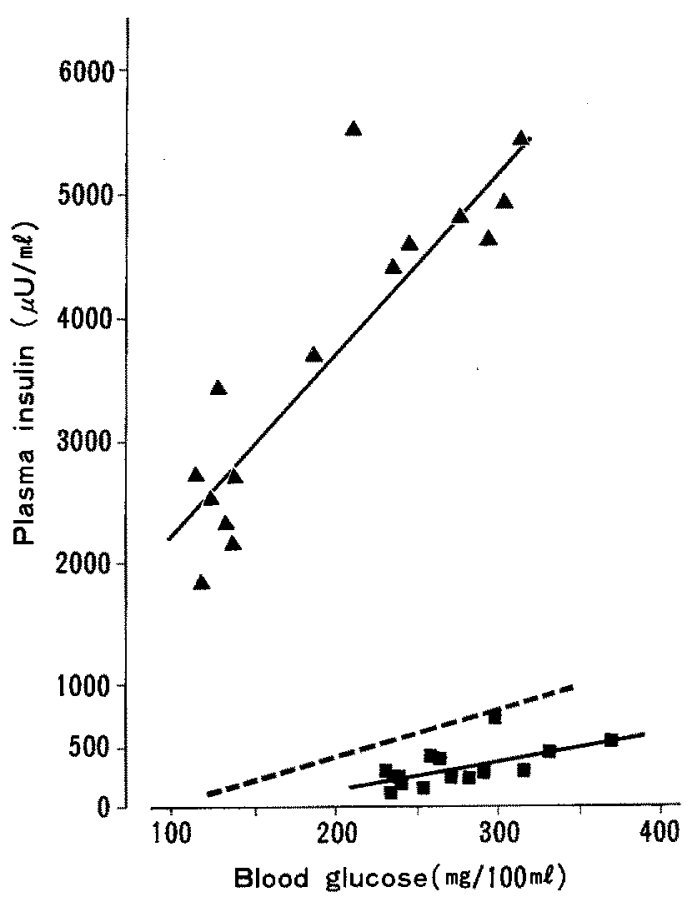

Fig. 2. Effects of $\alpha$ - and $\beta$-adrenergic antagonists on correlation between blood glucose and plasma insulin in fed KK mice. Phentolamine (A) or propranolol (E) was injected $1 \mathrm{~h}$ before blood collection as described in Materials and Methods. Regression lines are fitted by the method of the least-squares. The line for fed KK mice not treated with antagonists (Fig. 1B) is reproduced by a dotted line

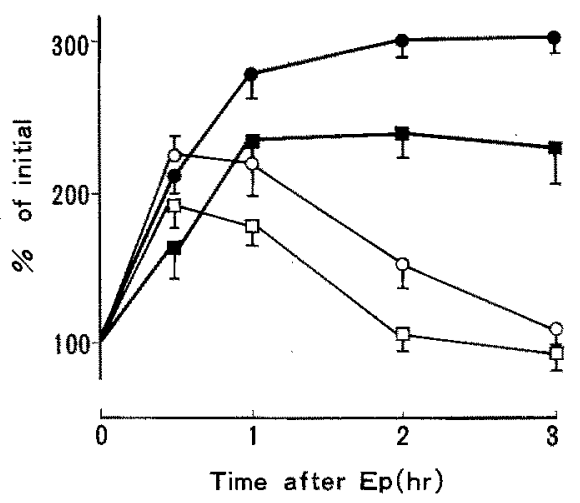

Fig. 3. Epinephrine-induced hyperglycaemia in fasted KK $(\mathbf{0}, \bullet)$ and ICR $(\square, O)$ mice. Six-week-old animals were fasted for 24 hours. Epinephrine (Ep) was injected subcutaneously in doses of $2 \mu \mathrm{g} / 10 \mathrm{~g}$ body wt $(\boldsymbol{m}, \square)$ and $5 \mu \mathrm{g} / 10 \mathrm{~g}(\bullet, 0)$. Means \pm SEM from 4-5 mice are shown. The blood glucose concentration immediately before epinephrine was $101 \pm 3$ and $132 \pm 5 \mathrm{mg} /$ $100 \mathrm{ml}$ for ICR and KK mice, respectively

The epinephrine-induced hyperglycaemia was more striking after $\alpha$-adrenergic blockade in KK mice than in ICR mice, and was no longer observable after $\beta$-adrenergic blockade. Combined administration of phentolamine and propranolol abolished 
Table 3. Effect of epinephrine and isoproterenol on concentration of blood glucose and plasma insulin in ICR and KK mice pretreated with $\alpha$ - or $\beta$-receptor antagonists

\begin{tabular}{|c|c|c|c|c|c|c|}
\hline \multirow[t]{2}{*}{ Pretreated with } & \multicolumn{3}{|c|}{ Blood glucose $(\mathrm{mg} / 100 \mathrm{ml})$} & \multicolumn{3}{|c|}{ Plasma insulin $(\mu \mathrm{U} / \mathrm{ml})$} \\
\hline & Control & Epinephrine & Isoproterenol & Control & Epinephrine & Isoproterenol \\
\hline \multicolumn{7}{|l|}{ ICR mice } \\
\hline None & $107 \pm 5(22)$ & $177 \pm 7(9)^{b}$ & $92 \pm 4(6)$ & $15 \pm 2(22)$ & $11 \pm 2(9)$ & $118 \pm 17(6)^{b}$ \\
\hline$\alpha$-Antagonist & $58 \pm 5(7)$ & $80 \pm 8(7)^{a}$ & & $38 \pm 6(7)$ & $30 \pm 7(7)$ & \\
\hline$\beta$-Antagonist & $94 \pm 4(12)$ & $99 \pm 7(4)$ & $102 \pm 3(4)$ & $19 \pm 2(12)$ & $10 \pm 1(4)^{a}$ & $38 \pm 7(4)^{b}$ \\
\hline$\alpha$-Plus $\beta$-antagonists & $77 \pm 8(5)$ & $87 \pm 8(5)$ & & $12 \pm 3(5)$ & $11 \pm 2(5)$ & \\
\hline \multicolumn{7}{|l|}{$K K$ mice } \\
\hline None & $136 \pm 10(18)$ & $227 \pm 17(10)^{\mathrm{b}}$ & $127 \pm 13(6)$ & $79 \pm 7(18)$ & $12 \pm 1(10)^{\mathrm{b}}$ & $215 \pm 13(6)^{b}$ \\
\hline$\alpha$-Antagonist & $73 \pm 7(8)$ & $120 \pm 8(5)^{\mathrm{b}}$ & & $104 \pm 32(8)$ & $107 \pm 24(5)$ & \\
\hline$\beta$-Antagonist & $135 \pm 6(15)$ & $126 \pm 7(4)$ & $144 \pm 17(4)$ & $57 \pm 8(15)$ & $11 \pm 1(4)^{b}$ & $74 \pm 13(4)^{b}$ \\
\hline$\alpha$-Plus $\beta$-antagonists & $89 \pm 27(3)$ & $99 \pm 18(4)$ & & $85 \pm 31(3)$ & $74 \pm 5(4)$ & \\
\hline
\end{tabular}

Values show the mean \pm SEM with number of animals in parentheses. ${ }^{a}(p<0.05)$ and ${ }^{b}(p<0.01)$ show significance levels for effect of the agonist

both actions of epinephrine on blood glucose and plasma insulin in KK and ICR mice. A difference in the plasma insulin concentration between $\mathrm{KK}$ and ICR mice, however, was observed under these conditions.

\section{Discussion}

Diabetes in KK mice is characterised by hyperglycaemia and hyperinsulinaemia. The hyperglycaemia is capable of causing hyperinsulinaemia because glucose acts as a potent stimulus of insulin secretion, while hyperinsulinaemia thus produced should alleviate hyperglycaemia because of the hypoglycaemic action of circulating insulin. Such a feedback control mechanism must be functioning to prevent excess hyperglycaemia and hyperinsulinaemia from taking place in non-diabetic animals. Thus, simultaneous occurrence of hyperglycaemia and hyperinsulinaemia as observed in KK mice must be in part due to impairment of the glucose lowering action of secreted insulin.

Even massive hyperinsulinaemia failed to lower the blood glucose concentration in the old KK mice in the fed state (Table 1) and the degree of hyperinsulinaemia was linearly related to the degree of hyperglycaemia (Fig. 1B), clearly indicating that in the old mice insulin was far less efficient in maintaining the blood glucose concentration within the normal range. In the fasted KK mice, however, the plasma concentration of insulin, although it was higher than the concentration in ICR mice, was inversely correlated with the blood glucose concentration (Fig. 1A). This inverse correlation suggests that insulin secreted was in fact effective in suppres- sing the blood glucose concentration under these conditions.

The slope of the regression line relating hyperinsulinaemia with hyperglycaemia in fed $\mathrm{KK}$ mice was much steeper than the slope of the line similarly drawn for fed ICR mice (Fig. 1B), and it became even steeper after $\alpha$-adrenergic blockade which shifted the regression line upwards (Fig. 2). On the contrary, the injection of a $\beta$-adrenergic antagonist into fed KK mice caused a downward shift of the regression line. Thus, a $\beta$-adrenergic mechanism may be involved in both enhanced secretion and blunted action of insulin which are characteristic of KK mice.

In the fasted KK mice, the injection of an $\alpha$ adrenergic antagonist caused insulin release which was effective in lowering the blood glucose concentration as a whole (Table 2). Even under these conditions, the plasma insulin concentration was positively correlated with the blood glucose concentration, in contrast to the negative correlation observed after $\alpha$ blockade in ICR mice.

In agreement with the concept that a $\beta$-adrenergic mechanism is responsible for insulin secretion, the injection of isoproterenol, a potent $\beta$-adrenergic agonist caused marked hyperinsulinaemia in ICR and KK mice (Table 3). This action of isoproterenol was largely blocked by propranolol. In contrast, epinephrine alone was very effective in lowering the plasma concentration of insulin when injected into KK mice presumably via stimulation of $\alpha$-adrenergic receptors as the epinephrine effect was efficiently reversed by phentolamine (Table 3 ). In the case of ICR mice, however, epinephrine was without effect on the plasma concentration of insulin. This disparity of the epinephrine action between KK and ICR mice would be accounted for by the difference in the 
plasma concentration of insulin before the catecholamine rather than by difference in the sensitivity of adrenergic receptors, since the plasma insulin level was lowered by epinephrine even in ICR mice provided that it had been elevated by feeding (data not shown). $\alpha$-Adrenergic inhibition of pancreatic insulin secretion in vivo by epinephrine was observed in normal rats as well only when sustained hyperinsulinaemia had been produced by a constant infusion of glucose into fasted rats [7].

Epinephrine-induced hyperglycaemia was abolished when ICR or KK mice had been injected with propranolol, but it was still observed after $\alpha$-blockade by phentolamine. Thus, epinephrine hyperglycaemia originated from stimulation of $\beta$-adrenergic receptors. This finding is in good agreement with Shikama and Ui [8] who reported that $\beta$-adrenergic inhibition of peripheral glucose utilisation was more responsible for epinephrine hyperglycaemia in rats rather than $\alpha$-adrenergic inhibition of insulin secretion. It is conceivable that mice share the same mechanism with rats for epinephrine-induced hyperglycaemia. Stimulation of $\alpha$-adrenergic receptors would cause enhanced glucose utilisation by muscle tissues [9] as well as retarded insulin secretion; this would be the reason why no hyperglycaemia occurred after $\alpha$-adrenergic stimulation as induced by the injection of epinephrine into propranolol-treated mice.

Further studies are now in progress as to how adrenergic mechanisms are involved in the insulin resistance characterising the genetic disorders of carbohydrate metabolism in KK mice.
Acknowledgements. We thank Mr. Yukio Amano for his excellent technical assistance.

\section{References}

1. Kondo K, Nozawa T, Tomida T, Ezaki K (1957) Inbred strains resulting from Japanese mice. Bull Exp Animals 6: 107-112

2. Nakamura M (1962) A diabetic strain of the mouse. Proc Jpn Acad 38: $348-352$

3. Nakamura M, Yamada K (1967) Studies on a diabetic (KK) strain of the mouse. Diabetologia 3: 212-221

4. Dulin WE, Wyse BM (1970) Diabetes in the KK mouse. Diabetologia 6: 317-323

5. Bergmeyer HU, Bernt E (1974) Determination with glucose oxidase and peroxidase. In: Bergmeyer HU (ed) Methods of enzymatic analysis, 2nd edn. Verlag Chemie, Weinheim. Academic Press, New York San Francisco London, p 1205-1212

6. Morgan CR, Lazarow A (1963) Immunoassay of insulin: two antibody system, plasma insulin levels of normal, subdiabetic and diabetic rats. Diabetes 12: 115-126

7. Sumi T, Ui M (1975) Potentiation of the adrenergic beta-receptor-mediated insulin secretion in pertussis-sensitized rats. Endocrinology 97: 352-358

8. Shikama H, Ui M (1975) Adrenergic receptor and epinephrineinduced hyperglycemia and glucose tolerance. Am I Physiol 229: $962-966$

9. Saitoh Y, Itaya K, Ui M (1974) Adrenergic $\alpha$-receptor-mediated stimulation of the glucose utilization by isolated rat diaphragm. Biochim Biophys Acta 343: 492-499

Received: June 9, 1980,

and in revised form: December 4, 1980

M. Ui, Ph. D.

Department of Physiological Chemistry

Faculty of Pharmaceutical Sciences

Hokkaido University

Sapporo

Japan 